\title{
A scoping review of Finnish doctoral dissertations in older people nursing science
}

Minna Stolt, Podiatrist, $\mathrm{PhD}$, University teacher/Researcher

University of Turku, Department of Nursing Science, Turku, FINLAND / Turku

University Hospital, Turku, Finland

e-mail: $\underline{\text { minna.stolt@utu.fi }}$

Sini Eloranta, RN, PhD, Clinical Lecturer, Lecturer

University of Turku, Department of Nursing Science, Turku, FINLAND

Turku University of Applied Sciences, Health and Wellbeing

e-mail: sinelo@utu.fi

Satu Elo, RN, PhD, Adjunct professor (docent), consultant

University of Oulu and Oulu University Hospital, Nursing Science and Health

Management Research Group, Medical Research Centre Oulu (MRC), Oulu, FINLAND e-mail: satu.elo@oulu.fi

Arja Isola, $\mathrm{PhD}$, Professor emerita

University of Oulu, Nursing Science and Health Management Research Group, Medical

Research Centre Oulu (MRC), Oulu, FINLAND

e-mail: arjaliisa.isola@gmail.com

Riitta Suhonen, RN, PhD, Professor/Director of Nursing

University of Turku, Department of Nursing Science / Turku University Hospital, City

of Turku, Welfare Division, Turku, FINLAND

e-mail: suhonen.riitta@kolumbus.fi; $\underline{\text { riisuh@utu.fi }}$

Corresponding author:

Minna Stolt, Podiatrist, $\mathrm{PhD}$, University teacher

University of Turku, Department of Nursing Science, Turku, FINLAND

e-mail: minna.stolt@utu.fi

Statement of ethical approval: Not needed in review papers.

Statement of funding: None.

Declaration of contribution of authors: The conception and design: MS, RS, SiE, SaE, $\mathrm{AI}$, analysis and interpretation of data: $\mathrm{MS}, \mathrm{SiE}, \mathrm{RS}$; the drafting of the article or revising it critically for important intellectual content $\mathrm{MS}, \mathrm{RS}, \mathrm{SiE}, \mathrm{SaE}, \mathrm{AI}$ and approval of the version to be published: MS, RS, SiE, SaE, AI.

Statement of conflict of interest: None. Acknowledgements: None. 


\begin{abstract}
Scientific research is important in guiding the development of evidence-based, costeffective and comprehensive health care. The purpose of this scoping review was to analyse the current stage of research in the field of older people nursing science based on doctoral dissertations completed in Finnish universities. Altogether 418 doctoral dissertations in nursing science were published (1990-2015), and 44 (11\% of all) representing older people nursing. The majority of the dissertations focused on patient and family or nursing activities. Usual topics were care procedures and clinical nursing (36\%); self-care ability, independence (23\%) and existence, being and feeling as an individual person (18\%). Only one randomised controlled trial was conducted. The main informants were older people (78\%) who were typically interviewed or surveyed. Research in older people nursing science in Finland is focusing on traditional clinical nursing settings. More innovative research is necessary from the perspective of health promotion and technological solutions.
\end{abstract}

Keywords: nursing science, older people, doctoral dissertations, scoping review. 


\section{Introduction}

Health and social services are undergoing rapid change and reforms due to many reasons, ${ }^{1}$ and populations are ageing. ${ }^{2}$ The aim of these reforms is to offer comprehensive services for citizens that are equal, consistent and based on the best evidence. ${ }^{1}$ In Finland, the current reform, i.e., integration of social and health services, is one of the largest to be implemented in the country, and no examples of such integration exist in the world. The Finnish Government programme ${ }^{3}$ has set the strategic goals, and one of these goals focuses on supporting older people's living at home and providing services at home. This integration places a strong emphasis on services that are comprehensive and readily available for individuals, i.e., social- and healthcare

clients. ${ }^{1,4}$ However, synthesized knowledge about the evidence of best practices, processes and activities of all stakeholders and those involved is needed to advance these reforms, the development of practices and national well-being.

Scientific research is important in guiding the development of evidence-based, costeffective and comprehensive practices and services. Nursing is an integral part of healthcare, as are nursing professionals as service providers. ${ }^{5}$ Nurses need to provide evidence-based nursing using the best available research findings in order to maximize the quality of care. Therefore, nursing science will continue to build the scientific 
evidence base for improved clinical care and quality of care for older people. ${ }^{6}$ However, it can be argued as to whether nursing research has been in the front line to support the integration and changes that have been and will be implemented in social and healthcare services. In the past, in the 1990s, nursing research focused strongly on qualitative analysis of patients' perceptions of their health, whereas patients' and nursing staff's perceptions of care and complex interventions to support health have, in general, been lacking. ${ }^{7}$ Doctoral programmes are in the front line when the aim is to produce new researchers for analysing, developing and evaluating health and social services, practices, processes, content, care procedures and outcomes. ${ }^{8}$ The current reforms are based on policy making, strategic planning and decision-making. However, the focus of interest is how the reforms are supported by research results. This scoping review focuses on analysing doctoral dissertations in nursing and caring science in the five Finnish universities.

Some corresponding analysis of dissertations in nursing science has been done. Those analyses focused on dissertations published by particular year, ${ }^{9}$ during certain time period $^{7,10}$ or topic from certain nursing area, such as nursing education, ${ }^{11}$ history of nursing, ${ }^{12}$ research ethics ${ }^{13}$ or certain research method. ${ }^{14}$ However, analysis focusing on older people nursing science is limited. 


\section{Research priorities}

Research priorities have been set in many ways in the area of older people care and services. However, the priority setting statements are quite old. Firstly, several countrybased analyses have been conducted. ${ }^{15,16,17}$ For example in Sweden research priorities were identified being human dignity in geriatric care, respectful transfers, continuity of care and exploring the characteristics of a caring encounter. ${ }^{17}$ Research improving clinical practice, assuring patients' wellbeing and a caring environment were prioritized. In China, research on care of the elderly was set as a high priority. ${ }^{15}$ Secondly, research priorities were set based on the care settings for older people. ${ }^{18}$ Research in nursing homes should focus on care of people with cognitive impairment, and the management of symptoms of dementia, end-of-life care, nutrition, polypharmacy, and developing approaches putting evidence-based practices into practice. ${ }^{18}$ Thirdly, research priorities were set on specific areas of older people nursing care, such as palliative geriatric care, ${ }^{19,20}$ end-of-life,${ }^{20}$ stroke ${ }^{21}$ or rehabilitation. ${ }^{16}$ Hinshaw $^{22}$ stated that research in older adults and their health and illness is considered highly important, and research is needed to identify older adults who are at high risk for loss of independence in daily activities or who are approaching increased dependence. In a review ${ }^{23}$, research priorities were identified for Nordic countries, such as promoting health and well-being, symptom management and coping with chronic conditions, care of the elderly, self-management of health and illness and restructuring healthcare systems. She identified that the care of 
the older adults was a research priority not only in Nordic countries but also in the United States, Europe and Africa.

Wellness, promoting health and preventing illness, self-management and quality of life of those having chronic conditions are key research areas in older people care. ${ }^{20}$ Lately the American Association of Colleges of Nursing ${ }^{24}$ has stated that the research on complex health issues of vulnerable groups of people such as older adults is needed.

\section{Background}

Today, people live longer than ever before, and the number of older people is expected to increase exponentially over the coming decades. ${ }^{25}$ Finland has one of the fastest growth rates of older people in the world. ${ }^{26}$ In Sweden, the increase in the number of older people aged 80 and over is expected to double by $2060 .{ }^{27}$ Predictions show that the proportion of people aged 75 or over is expected to rise by $59,000(10 \%)$ in 2020 and by $61,758(15 \%)$ in $2040 .{ }^{28}$ Similarly, in Europe, the number of people aged 80 years or over is projected to almost triple from 21.8 million in 2008 to 61.4 million in $2060 .^{29}$ These demographic changes pose challenges for society and have implications for the provision of health care and social services.

As in many other countries, ${ }^{30}$ the main goal of older age policy in Finland is to support 
older people's autonomy and to help them live in their own homes for as long as possible. ${ }^{3,31}$ The trend is that an increasing proportion of older people receive health care and social services at home. ${ }^{31-33}$ Older people prefer to remain in their homes for as long as possible rather than to institutionalised. By staying in their own homes they are able to maintain the integrity of their social networks, preserve environmental landmarks, and enjoy a better quality of life. ${ }^{34,35}$ Furthermore, admission to nursing homes or sheltered housing is expensive, both in terms of public and private finances. ${ }^{36,37}$ However, this does not mean that institutional care is not needed. ${ }^{38}$ It has been stated that today, people live healthier lives than earlier generations. ${ }^{39-41}$ However, health inequalities have been found among older populations with different classifications of socio-economic groups. ${ }^{42}$ The health and functional capacity of older people is threatened due to many chronic conditions, meaning a need for care and services. ${ }^{43}$ However, it is important to recognise the fact that older people are not a homogenous group but consists of people within a wide range of ages (at the moment, 63-109 years), the majority of them relatively fit and healthy. In Finland, for example, only one out of four of those aged 75 or over use services on a regular basis. ${ }^{44}$

To summarise, research is urgently needed for the development of quality care and services. Reviews of published doctoral dissertations conducted from time to time may help in drawing conclusions about the state of the research and the need for future 
research. However, research on this group of people, older people, has some special features that need to be taken into account. For researchers, involving older people in research is a challenge as some of them are vulnerable. ${ }^{44}$ Possible demands for some additional time for data collection and the application and use of different methods may require special skills in this population. ${ }^{45}$ Furthermore, it has been found that e.g. research on ethical issues in the care of older people is limited, ${ }^{46}$ and access to research sites in the context of older people care settings may be difficult. ${ }^{47-48}$ Including people with cognitive deficits and similar is challenging, ${ }^{49}$ and usually, older people are excluded from the studies. ${ }^{50}$ For these reasons, research on older people may be limited.

However, there is a discrepancy between the increasing number of older people as healthcare clients and the limited or even minor number of studies in this field. ${ }^{49}$ Furthermore, worldwide media report poor health care for older people, and concerns are raised about the shortage of well-educated staff in older people care and the quality of care provided for older people. ${ }^{51}$ Nursing research can be one tool that can make a contribution to the discussion of older people, their health, nursing care, environment and value base. 
The purpose of this scoping review was to analyse the current stage of research in the field of older people nursing science based on doctoral dissertations completed in Finnish universities. Scoping reviews aim to provide a synthesis of the size and scope of research and identify the nature of research evidence for further research and for informing policy makers. The specific research questions were:

- What is the focus of older people nursing science research?

- What methods have been used in older people nursing science research?

- What settings are the studies focused on?

\section{METHODS}

\section{Design and sample}

This study employed a scoping literature review ${ }^{52}$ of doctoral dissertations in nursing science. The inclusion criteria for the doctoral dissertation studies were: 1) the dissertation was focused on older people nursing or older people in general (as research informants, regarding their care and services), 2) the dissertation was published from the earliest through 2015 and 3) the dissertation be longed to one of the five doctoral programmes in nursing science in Finland. No specific exclusion criteria were set.

The data were gathered in three phases. Firstly, in the identification phase, the publication lists of doctoral dissertations in five universities in Finland (University of 
Eastern Finland, University of Oulu, University of Tampere, University of Turku and Åbo Akademi) having doctoral programmes in nursing or caring science were collected. Secondly, in the screening phase, the publication lists of doctoral dissertations in nursing science from different universities were examined on title and abstract levels and potential dissertation were selected based on the criteria set. The researchers worked independently on the first phase and discussed the results and decided which dissertations were to be analysed further. Thirdly, in the eligibility phase, the selections were confirmed in the research group.

Altogether 418 doctoral dissertations were published between 1990 and 2015 in the five Finnish universities where nursing science is taught. Of the identified 418 dissertations 44 were selected for the final analysis in the eligibility phase. As a result of this step-bystep selection process, a systematic analysis of the remaining 44 dissertations was conducted by three researchers.

\section{Data analysis}

A systematic analysis of the 44 dissertations was conducted using a data collection sheet. The data collection sheet included: author, year, name of university, type of dissertation (monography, compilation with original publications), aim, paradigm area

in nursing science (patient, health, nursing, environment according to Kim's typology, ${ }^{53}$ 
target group/data, methods, setting, main goal of the whole study and other remarks. Kim's typology ${ }^{53}$ was selected based on the comprehensiveness of the core areas in nursing science and one study could include more than one core areas. This information was systematically collected on the data collection sheet and used as data for this review. The data were analysed using quantification with frequencies and percentages and content analysis by searching responses to research questions.

The abstracts of the dissertations were the sources of the information. Terms and concepts used by researchers in the abstracts with the help of dissertation title and keywords were used and no interpretations were done.

Topics of the dissertations were analysed with inductive content analysis. The manifest content was analysed and the units of analysis (words or sentences) were condensed, and those containing aspects related to each other were grouped together into categories (Table 3).

\section{RESULTS}

\section{Description of dissertations}

A total of 44 doctoral dissertations were identified out of 418 , which is about $11 \%$ of all dissertations in the five universities offering a $\mathrm{PhD}$ programme in nursing science in 
Finland. Slightly more than half of the focus dissertations $(n=23,52 \%)$ were monographs while the other half were compilation dissertations $(n=21,48 \%)$ of four to six original articles and a summary. In total, 14 (32\%) were completed in the University of Turku, $6(14 \%)$ in the University of Tampere, $8(18 \%)$ in the University of Eastern Finland, 14 (32\%) in the University of Oulu and 2 (5\%) in Åbo Akademi. Only three out of the $44(7 \%)$ dissertations were completed by international $\mathrm{PhD}$ candidates in the University of Oulu ${ }^{54,55}$ and in the University of Eastern Finland ${ }^{56}$.

Table 1 here

\section{Focus of older people nursing science research}

Regarding the four main areas of the nursing paradigm, the majority of the dissertations focused on patient/family or nursing activities. Only one dissertation ${ }^{57}$ focused clearly on environment (Table 2). Regarding the topics, the majority of the dissertations focused on care procedures and clinical nursing $(n=16,36 \%)$, self-care ability, independence or related issues $(n=10,23 \%)$, existence, being and feeling as an individual person $(n=8,18 \%)$, quality of life, life satisfaction or well-being $(n=6,14 \%)$. Only two dissertations (5\%) focused on knowledge or learning of the older people. Two dissertations (5\%) focused on transition between home and institutions (Table 3).

Table 2 here

Table 3 here 
Regarding the main target/goals of the dissertations in nursing science, three dissertations included the development or testing of a new instrument such as foot health,$^{58}$ risk assessment for pressure ulcer ${ }^{59}$ and appraisal of self-care agency, validation for Finnish population. ${ }^{60}$ A more usual goal was development of a model, ${ }^{61-63}$ theory ${ }^{57,64}$ or substantive theory. ${ }^{65-67}$ One dissertation was on developing a programme ${ }^{68}$ and one was a randomised controlled trial of a self-care programme aimed at older people. ${ }^{56}$ One dissertation was a historical analysis about the evolution of geriatric nursing. ${ }^{69}$ The rest produced and generated new knowledge in nursing science focusing on issues such as the description of the phenomenon under consideration.

\section{Informants and research methods of the actual dissertations}

\section{Informants and contexts}

The main informants in the dissertations were mainly older people $(n=34,77 \%)$ and their family members $(n=13,30 \%)$ or nurses or other healthcare professionals $(n=22$, $50 \%)$. Many dissertations combined several informant groups. Nurse managers $(n=3$, $7 \%)$ or students $(\mathrm{n}=2,5 \%)$ were used as informants in some dissertations. One study (2\%) was registry-based. ${ }^{70}$ Sample sizes varied greatly, for example in patient informants from 7 to 4,113 and in nurse or healthcare professionals from 7 to 8,157 . 
Care settings were home $(\mathrm{n}=18,37 \%)$ or community in general $(\mathrm{n}=5,10 \%)$, different institutions including primary health care centres, nursing homes, residential homes $(n=17,35 \%)$, hospital settings, acute in-patient or outpatient clinics $(n=6,12 \%)$, rehabilitation settings $(n=1,2 \%)$ or others, such as education institutions $(n=2,4 \%)$.

\section{Data collection methods}

As many of the dissertations were compilations of original publications they included many different methods joined together. Interviews and surveys were the most used data collection methods. Observation was used in some studies. ${ }^{71-75}$ Written texts such as documents, diaries or essays were used in some dissertations. ${ }^{69,70,73,74,76-78}$ Clinical measurement or assessments were used in some studies. ${ }^{58,79-83}$ Videotaping was used in only two studies. ${ }^{72,82}$

\section{DISCUSSION}

The analysis of the Finnish doctoral dissertations in nursing science revealed the limited amount of studies focusing on older people and the care settings of older people. These dissertations were mainly from two universities, Turku and Oulu. Most often the research informants were older people, their relatives or different professionals, many studies including several informant groups. 
Using older people as informants in these studies can be judged as being important and appropriate for the development of services for individual people aimed at in many strategies. ${ }^{1,3}$ In Sweden, Bäck-Pettersson et al. ${ }^{17}$ revealed essential areas for future patient-related nursing research and found that the most highly ranked areas of nursing research were preserving human dignity in geriatric care, respectful transfers, and continuity of care and exploring the characteristics of a caring encounter relative to patient welfare, the healthcare organization and the nursing profession. Based on our review the societal viewpoint was largely missing from the dissertation topics. However, it can be argued as to whether nursing research is otherwise focused on the most appropriate issues in current healthcare, as a minority of the studies dealt with the service systems and their effectiveness. None of the studies focused on costeffectiveness. Another criticism besides the topics is the use of small and often also regional samples which are neither representative or generalizable.

Based on the results, there is a need for future research where both nursing educators and students are in the focus. Only one study focused on nursing education regarding older people. Luukka ${ }^{84}$ investigated meaningful learning experiences of the newly graduated practical nurses in older people care. A study by Deschodt et al. ${ }^{85}$ reported that knowledge, competencies, and attitudes necessary to care for older people are 
urgently needed, but its complexity is not recognized. Research on education of nurses needs further recognition. Potter el. al. ${ }^{86}$ recommended that it would be valuable to conduct a longitudinal study using education sessions and tools to explore students' values and beliefs in relation to gerontological care over the span of their nursing programme. In Europe there is growing concern as to how to get a sufficient number of motivated and qualified nurses to work with older people both in the community and hospitals. The nursing educators have enormous potential when it comes to raising the profile of care of older people by preparing and supporting students. ${ }^{87}$

Two main target settings were used, home and similar settings and institutional care settings. Research in home and community settings is urgently needed as care is strongly moving out from institutions to homes. ${ }^{1,3,4}$ International research has shown that as people and generations are getting older, there is a strong increase in the number of the oldest old, but also vulnerability and frailty is apparent in the lives of older people..$^{29,31}$ Thus, early support for a healthy life style, health education and prevention of diseases is needed. ${ }^{39-41}$ In addition, other important aspects/areas of life need to be taken into serious consideration, such as culture, art, and recreational activities in society, arenas and care settings for older people. ${ }^{6}$ 
The concepts used in the doctoral studies were very general in their nature, such as quality of life, existence, being and feeling as an individual person, life satisfaction or well-being. Support and maintenance of independence, self-care, self-management and ability to function were present in the dissertations, providing a positive viewpoint for the developing care and services to support their own resources, initiatives, responsibility and roles, which is in line with the strategies. ${ }^{1,4,31,33}$ As older people are frequent service users ${ }^{88}$ seamless care pathways, transition and collaboration are need to support independence and effective care. ${ }^{89}$ Only two studies focused on this service structure and older people's transition in the services. This is a clear lack and warrants further research.

The most frequently used research methods were utilised, including interviews and questionnaire surveys. Surprisingly, only one study used a register as data source. This is interesting as the Nordic countries are known for their detailed registers for health and social related issues, care and services such as RAI, ${ }^{90}$ interRAI ${ }^{91}$ or the Finnish Sotkanet. ${ }^{92}$ Reasons for this may be the underdeveloped methodology in nursing research, focus on hermeneutics and phenomenological approaches informed by qualitative data sources, restricted access or incomplete skills in statistics and data mining and information technology. Instead of using big data ${ }^{93}$ and already existing registry data sources qualitative studies with few informants continue to occupy a strong 
position in nursing research. From the early stages of science and discipline development descriptive studies and experiences of care and services are needed. Based on this knowledge, many substantive theories have been developed, but besides developing theories, there is also need for testing them and conducting intervention studies to test the proposed associations between the identified concepts. It is also noticeable that quite small sample sizes were used in many studies.

There was clear evidence of re-conceptualisation in the field under study over the years, starting from geriatric nursing, followed by gerontological nursing and older people nursing science. This can be seen as being in line with the revolution of nursing science. ${ }^{94,95}$ There remains a strong need to continue to grow the field of gerontological nursing and aging sciences. There is a need to work diligently for health system reforms and to develop and support gerontological nursing leaders in their work in the care settings for older people. ${ }^{95}$ The authors ${ }^{95}$ call for innovations for older adults, based on research, addressing an array of diseases and conditions affecting human systems, embedded in a variety of environments, including in-home care, subsidised housing communities, nursing homes, assisted living facilities, memory care units, and rural community environs. The inclusion of the ageing theories in nursing science is strongly recommended and could lead to innovations. ${ }^{94}$ 


\section{Limitations and methodological considerations}

This review has some limitations. Firstly, this review focused only on nursing science in the Finnish context. Similar research topics certainly appear in gerontology, health management sciences, health and human services informatics, geriatrics and social gerontology and biomedical sciences. However, knowing the current state of the nursing discipline may make it easier to focus on multidisciplinary collaborative research. Furthermore, this review focused on the Finnish doctoral dissertations. The next step would be the analysis of the Nordic perspective on older people nursing science and comparison of the volume and knowledge base in the Nordic countries. Secondly, this review focused on doctoral dissertations. It is evident that in the field of health sciences there are plenty of research articles focusing on older people and their care conducted by many research groups, which were not included in this review. However, the doctoral dissertation is usually a starting point to a research career, and in dissertations the research area is widely explored, combining data from different sources and using a variety of methods and perspectives. In addition, researchers often continue with the same study topics later in their careers. Thirdly, this review used abstracts of the dissertations as data. Abstracts can vary based on their contents and therefore do not produce detailed information. ${ }^{96}$ Despite this, the abstracts were informative enough and produced sufficient information to proceed with data analysis. Fourthly, no large-scale analysis of the quality of the studies was included. This is in accordance with the 
scoping review method ${ }^{97}$ However, as the analysed documents are dissertations, they are subject to the formal quality requirements concerning doctoral dissertations set by the faculties. In addition, the quality of the original publications included in the compilation dissertations had under gone a quality evaluation in the peer review journals.

The trustworthiness of this review was supported by using many researchers in the retrieval process of the dissertations. Although the analysis was performed by two researchers, the results were discussed within the research team and a consensus was achieved.

\section{Conclusions}

This coping review shed light on the nursing research in the Finnish five doctoral programmes since the beginning through the end of 2015. One in every ten of the Finnish dissertations focused on older people nursing science. These studies were mainly from two universities describing the research strategies and profiles of the doctoral programmes. The focus of the studies was older people, their situation and lives. The research is mainly focused on traditional clinical nursing settings and more innovative research is necessary from the perspective of health promotion and technological solutions. This is important for producing knowledge and responding to 
the demand for person-centred services and care highlighted in several European strategies.

Representing the voice of the service users is neglected in the development of services but requires strong emphasis in the reforms being implemented today. Therefore, the research focus can be judged to be adequate. A weakness is the number of the dissertations. Further research is needed to strengthen the theory basis of older people nursing science in education, care environment, the integrating healthcare service systems, processes, care protocols and the effectiveness of different nursing interventions in older people. 


\section{References}

* dissertation included in the review

1. Ministry of Social Affairs and Health. Sote integration - working for clients. Ministry of Social Affairs and Health news. http://stm.fi/artikkeli/-/asset_publisher/soteintegraatio-on-asiakkaan-

asialla?_101_INSTANCE_yr7QpNmlJmSj_languageId=en_US (2015, accessed 12 October 2016).

2. US Census Bureau. Statistics. http://www.census.gov/topics/population.html (2016, accessed 12 October 2016).

3. The Finnish Government Programme 2015. Finland, a land of solutions. Strategic Programme of Prime Minister Juha Sipilä's Government. Government Publications 12/2015. Edita Prima.

4. Ministry of Social Affairs and Health. Hallitusohjelman toimeenpanosuunnitelma STM:n hallinnonalalle 2016-2019. Raportteja ja muistioita 2016:2. http://urn.fi/URN:ISBN:978-952-00-3693-5 (2016, accessed 12 October 2016). 5. WHO. Working together for health. The World health report. http://www.who.int/whr/2006/en/ (2006, accessed 12 October 2016). 6. Grady P. Advancing the health of our aging population: A lead role for nursing science. Nurs Outlook 2011; 59: 207-9. 
7. Academy of Finland 2003. Nursing and caring sciences. Evaluation report.

Publications of the Academy of Finland 12/2003. Painopörssi Oy, Helsinki.

8. Finnish Doctoral Education Network in Nursing Science.

http://www.utu.fi/en/units/med/units/hoitotiede/doctoral_programme/Pages/home.aspx (2016, accessed 10 August 2016).

9. Zeng Y and Pang S. Reviewing the trends of nursing doctoral thesis research in Hong Kong. OJN 2012; 2: 346-350.

10. Baggio MA, Rodrigues MA, Erdmann AL, et al. Production of nursing thesis and dissertations in Portugal, 2000-2010: a bibliometric study. Text Context Nursing 2014; 23: $250-60$.

11. Vierula J, Stolt M, Salminen L, et al. Nursing education research in Finland--A review of doctoral dissertations. Nurse Educ Today 2016; 37: 145-154.

12. Lukana A, Salminen L, Kaartinen M, et al. Historical theses on nursing and caring sciences in Finland: a literature review. Scand J Caring Sci 2013; 27: 774-784.

13. Kjellström S and Fridlund B. Status and trends of research ethics in Swedish nurses' dissertations. Nurs Ethics 2010; 17: 383-392.

14. Donnelly JP. A systematic review of concept mapping dissertations. Eval Program Plan 2017; 60: 186-193.

15. Yin TJ, Hsu N, Tsai SL, et al. Priority-setting for nursing research in the Republic of China. J Adv Nurs 2000; 32: 19-27. 
16. Chang E, Ho CK, Yuen AC, et al. A study of clinical nursing research priorities in aged care: a Hong Kong perspective. Contemp Nurse 2003; 15: 88-98.

17. Bäck-Pettersson S, Hermansson E, Sernert N et al. Research priorities in nursing--a Delphi study among Swedish nurses. J Clin Nurs 2008; 17: 2221-2231.

18. Morley JE, Caplan G, Cesari M, et al. International survey of nursing home research priorities. J Am Med Dir Assoc 2014; 15: 309-312.

19. Unroe KT and Meier DE. Research priorities in geriatric palliative care: policy initiatives. J Palliat Med 2013; 16: 503-1508.

20. National Institute of Nursing Research. The NINR Strategic Plan: Advancing Science, Improving lives. A Vision for Nursing Science.

https://www.ninr.nih.gov/aboutninr/ninr-mission-and-strategic-plan (2016, accessed 19 December 2016)

21. Pollock A, St George B, Fenton M, et al. Top 10 research priorities relating to life after stroke--consensus from stroke survivors, caregivers, and health professionals. Int $J$ Stroke 2014; 9: 313-20.

22. Hinshaw AS. Nursing knowledge for the 21st century: opportunities and challenges. J Nurs Scholarsh 2000; 32: 117-123.

23. Hinshaw, AS. Building excellence in science: Setting priorities for knowledge development. In E. Hamrin \& M. Lorensen (Eds.), Nordic symposium, perspectives on priorities in nursing science (No.1, 15-28). Stockholm: Vardalstiflelsen. 1997. 
24. American Association of Colleges of Nursing. Position Statement. Nursing research. http://www.aacn.nche.edu/publications/position/nursing-research (2016, accessed 19 December 2016)

25. OECD. Society at a Glance: OECD Social Indicators 2014. http://www.oecdilibrary.org/social-issues-migration-health/society-at-a-glance-2014_soc_glance-2014en (2014, accessed 10 August 2016).

26. Statistics Finland. Development of age structure. www.findikaattori.fi/en/81 (2014, accessed 10 August 2016).

27. Statistics Sweden. Demographic Reports. The Future Population of Sweden 20092060. 2009, Statistics, Sweden.

http://www.scb.se/statistik/_publikationer/BE0401_2009I60_BR_BE51BR0901ENG.pd f (2009, accessed 8 August 2016).

28. Statistics Finland. Population projection 2012 according to age and sex 2012 2060, whole country. https://www.stat.fi/til/vaenn/2012/vaenn_2012_2012-0928 en.pdf. (2013, accessed 12 August 2016).

29. Eurostat. Regional population projections EUROPOP 2008: Most EU regions face older population profile in 2030. Statistics in focus 1/2010.

http://ec.europa.eu/eurostat/documents/3433488/5564440/KS-SF-10-001EN.PDF/d5b8bf54-6979-4834-998a-f7d1a61aa82d. (2010, accessed 8 August 2016) 
30. WHO. Global Health and Aging.

http://www.who.int/ageing/publications/global_health.pdf (2011, accessed 8 August 2016).

31. National Institute for Health and Welfare/Finland. Socially sustainable Finland 2020. Strategy for social and health policy. http://stm.fi/en/strategy (2011, accessed 8 August 2016).

32. Ministry of Health and Social Affairs/Sweden. Developments in elderly policy in Sweden. http://www.government.se/sb/d/2197/a/15498 (2008, accessed 13 June 2016). 33. Ministry of Social Affairs and Integration/Denmark. Social Policy in Denmark. http://sm.dk/en/international-priorities/publications/social-policy-in-denmark (2011, accessed 10 June 2016).

34. Lee DT, Woo J and Mackenzie AE. A review of older people's experiences with residential care placement. $J$ Adv Nurs 2002; 37: 19-27.

35. Mahler M, Sarvimäki A, Clancy A, et al. Home as a health promotion setting for older adults. Scand J Public Health 2014; 42: 36-40.

36. Luppa M, Luck T, Weyerer S, et al. Prediction of institutionalization in the elderly. A systematic review. Age Ageing 2010; 39: 31-38.

37. OECD. OECD Factbook 2014. Organisation for Economic Co-operation and Development. http://www.oecd-

ilibrary.org/docserver/download/3013081e.pdf?expires=1428050757\&id=id\&accname= 
guest\&checksum=4695A22D8FC815425443A11B4E6ADB1F $(2014$, accessed 10 October 2016).

38. National Institute for Health and Welfare/Finland. Quality recommendation to guarantee a good quality of life and improved services for older persons. http://urn.fi/URN:ISBN:978-952-00-3443-6 (2013, accessed 10 June 2016). 39. Wilhelmson K, Allebeck P and Steen B. Improved health among 70-year olds: comparison of health indicators in three different birth cohorts. Aging Clin Exp Res 2002; 14: 361-70.

40. Sacuiu S, Gustafson D, Sjögren M, et al. Secular changes in cognitive predictors of dementia and mortality in 70-year-olds.Neurology 2010; 75: 779-785.

41. Falk H, Johansson L, Östling S, et al. Functional disability and ability 75-year-olds: a comparison of two Swedish cohorts born 30 years apart. Age Ageing 2014; 43: 63641.

42. Afshar S, Roderick PJ, Kowal P, et al. Multimorbidity and the inequalities of global ageing: a cross-sectional study of 28 countries using the World Health Surveys. BMC Public Health 2015; 13; 15: 776.

43. Eurostat. Healthy life years statistics. http://ec.europa.eu/eurostat/statisticsexplained/index.php/Healthy_life_years_statistics (2016, accessed 11 August 2016). 44. Suhonen R, Stolt M and Leino-Kilpi H. Older people in long-term care settings as research informants: Ethical challenges. Nurs Ethics 2013; 20: 551-567. 
45. Pesonen H-M, Remes AM and Isola A. Ethical aspects of researching subjective experiences in early-stage dementia. Nurs Ethics 2011; 18: 651-661.

46. Suhonen R, Stolt M, Launis V, et al. Research into the study of ethics in elderly nursing care - A Literature Review. Nurs Ethics 2010; 17: 337-352.

47. Nygård L. How can we get access to the experiences of people with dementia? Scand J Occup Ther 2006; 13: 101-112.

48. Jacelon CS. Older adults' participation in research. Nurse Res 2007; 14: 64-73. 49. Beattie E. Research participation of individuals with dementia. Decisional capacity, informed consent, and considerations for nurse investigators. Res Gerontol Nurs 2009; 2: $94-102$.

50. Taylor JS, DeMers SM, Vig EK, et al. The disappearing subject: Exclusion of people with cognitive impairment and dementia from geriatrics research. $J$ Am Geriatr Soc 2012; 60: 431-419.

51. Karlstedt M, Wadensten B, Fagerberg I, et al. Is the competence of Swedish Registered Nurses working in municipal care of older people merely a question of age and postgraduate education? Scand J Caring Sci 2015; 29: 307-316.

52. Colquhoun HL, Levac D, O'Brien KK, et al. Scoping reviews: time for clarity in definition, methods, and reporting. Journal of Clinical Epidemiology 2014; 67: 12911294. 
53. Kim H S. The nature of theoretical thinking in nursing. $3^{\text {rd }}$ edition. Springer Publishing Company: New York, 2010.

54. Zeleznik D. Self-care of home-dwelling elderly people living in Slovenia. $\mathrm{PhD}$ Thesis, Acta Universitatis Ouluensis D954, University of Oulu and University of Maribor, 2007.*

55. Habjanic A. Quality of institutional elderly care in Slovenia. PhD Thesis, Acta Universitatis Ouluensis D1021, University of Oulu, 2009.*

56. Tan KK. Enhancing health resources among older people in the community using a salutogenesis-based intervention programme. $\mathrm{PhD}$ Thesis, Dissertations in Health Sciences 314, University of Eastern Finland, 2015.*

57. Elo S. A theory of an environment supporting the well-being of home-dwelling elderly from Northern Finland. PhD Thesis, Oulun yliopisto, hoitotieteen ja terveyshallinnon laitos. (In Finnish, English abstract), 2006.*

58. Stolt M. Foot health in older people - Development of a preventive, evaluative instrument for nurses. PhD Thesis, Annales Universitatis Turkuensis D1066, University of Turku, 2013.*

59. Lepistö M. Pressure ulcer risk assessment in long-term care. Developing an instrument. PhD Thesis, Annales Universitatis Turkuensis D588, University of Turku, 2004.* 
60. Sonninen AL. Testing reliability and validity of the Finnish version of the appraisal of self-care agency (ASA) scale with elderly Finns. PhD Thesis, Kuopion yliopiston julkaisuja E44, University of Kuopio, 1997.*

61. Lukkaroinen R. Shared-responsibility model to enable the elderly to live at home. Modes of living of home care clients aged over 75 and the costs and functional contents of the different service structure models. PhD Thesis, Acta Universitatis Ouluensis D698, University of Oulu. (In Finnish, English abstract), 2008.*

62. Salin S. Lyhytaikaisen laitoshoidon reaalimalli vanhuksen kotihoidon osana. (In Finnish). PhD Thesis, Acta Universitatis Tamperensis 1346, University of Tampere, 2008.*

63. Valta A. Iäkkäiden päivittäinen suoriutuminen kotona. Teoreettinen malli iäkkäiden kotona asuvien päivittäisestä suoriutumisesta kotisairaanhoitajien ja iäkkäiden näkökulmasta. (In Finnish). PhD Thesis, Acta Universitatis Tamperensis 1368, University of Tampere, 2008.*

64. Backman K. Self-care of home-dwelling elderly. PhD Thesis, University of Oulu, (In Finnish, English abstract), 2001.*

65. Nores T. The experience of existence. A conceptual and empricial analysis concerning the experience of existence of an elderly female patient. $\mathrm{PhD}$ Thesis, University of Turku, (In Finnish, English abstract), 1992.* 
66. Koponen L. Iäkkään potilaan siirtyminen kodin ja sairaalan välillä -substantiivinen teoria selviytymisestä ja yhteistyöstä. PhD Thesis, Acta Universitatis Tamperensis 974, University of Tampere (In Finnish), 2003.*

67. Pesonen H-M. Managing life with a memory disorder: the mutual processes of those with memory disorders and their family caregivers following a diagnosis. $\mathrm{PhD}$ Thesis, Acta Universitatis Ouluensis D1290, University of Oulu, 2015.*

68. Laitinen P. The participation of informal caregivers and care quality in the hospital care of elderly patients aged 75 or older: a time series study in three care settings. $\mathrm{PhD}$ Thesis, Kuopion yliopiston julkaisuja E39, University of Kuopio, 1996.* 69. Paasivaara L. Goals and actual practice. Multi-level analysis of the evolution of Finnish geriatric nursing from the 1930s till the 2000s. PhD Thesis, Acta Universitatis Ouluensis D 707, University of Oulu (In Finnish, English abstract), 2002.*

70. Turjamaa R. Older people's individual resources and reality in home care. $\mathrm{PhD}$ Thesis, Publication of University of Eastern Finland 255, University of Eastern Finland, 2014.*

71. Liukkonen A. Dementoituneen potilaan perushoito laitoksessa. PhD Thesis, Annales Universitatis Turkuensis C81, University of Turku (In Finnish), 1990.* 72. Routasalo P. Touch in the nursing care of elderly patients. PhD Thesis, Annales Universitatis Turkuensis D258, University of Turku, 1997.* 
73. Klemola A. Leaving one's home for the nursing home: ethnography on the transition phase of old people living in Ostrobotnia. $\mathrm{PhD}$ Thesis, Kuopion yliopiston julkaisuja E 138, University of Kuopio (In Finnish, English abstract), 2006.* 74. Savikko N. Loneliness of older people and elements of an intervention for its alleviation. PhD Thesis, Annales Universitatis Turkuensis D808, University of Turku, 2008.*

75. Saarnio R. The use of physical restraints in institutional elderly care. $\mathrm{PhD}$ Thesis, Acta Universitatis Ouluensis D1024, University of Oulu (In Finnish, English abstract), 2009.*

76. Muurinen S. Hoitotyö ja hoitohenkilöstön rakenne vanhusten lyhytaikaisessa laitoshoidossa. PhD Thesis, Acta Universitatis Tamperensis 936, University of Tampere (In Finnish), 2003.*

77. Teeri S. Ethical problems in long-term institutional care of older patients in the field of integrity. PhD Thesis, Annales Universitatis Turkuensis D774, University of Turku, 2007.*

78. Välimäki T. Family caregivers of persons with Alzheimer's disease: focusing on the sense of coherence and adaptation to caregiving: an ALSOVA follow-up study. $\mathrm{PhD}$ Thesis, Publications of Eastern Finland 116, University of Eastern Finland, 2012.* 79. Arve S. Recognition of depressive elderly people in health care services. $\mathrm{PhD}$ Thesis, Annales Universitatis Turkuensis D364, University of Turku, 1999.* 
80. Pirilä R. Oral care of the elderly in the institutions. PhD Thesis, Annales

Universitatis Turkuensis C180, University of Turku (In Finnish, English abstract), 2002.*

81. Soini H. Nutrition in patients receiving home care. $\mathrm{PhD}$ Thesis, Annales Universitatis Turkuensis D639, University of Turku, 2004.*

82. Ravelin T. Dance performance as an intervention in the care of elderly persons with dementia. PhD Thesis, Acta Universitatis Ouluensis D986, University of Oulu (In Finnish, English abstract), 2008.*

83. Härkönen P. Life satisfaction and health. A resource oriented study of elderly persons. PhD Thesis, Acta Universitatis Ouluensis D1186, University of Oulu (In Finnish, English abstract), 2012.*

84. Luukka K. Meaningful Learning Experiences of the Newly Graduated Practical Nurses in the Elderly Care: Feeling Mirror as a Reflector of Meaningful Learning Experiences. PhD Thesis, Kuopion yliopiston julkaisuja E142, University of Kuopio (In Finnish, English abstract), 2007.*

85. Deschodt M, de Casterlé BD and Milisen K. Gerontological care in nursing education programmes. $J$ Adv Nurs 2010; 66: 139-48.

86. Potter G, Clarke T, Hackett S, et al. Nursing students and geriatric care: The influence of specific knowledge on evolving values, attitudes and actions. Nurse Educ Pract 2013; 13: 449-453. 
87. Koh LC. Student attitudes and educational support in caring for older people - A review of literature. Nurse Educ Pract 2012; 12: 16-20.

88. National Institute for Health and Welfare. Primary health care services 2013. Statistical report.

http://www.julkari.fi/bitstream/handle/10024/120380/PTH2013_raportti_fi_sv_en.pdf?s equence=7 (2014, accessed 10 August 2016).

89. Leichsenring K. Developing integrated health and social care services for older persons in Europe. Int J Integr Care 2004; 4: e10

90. National Institute for Health and Welfare. Tietoa RAI-järjestelmästä. https://www.thl.fi/fi/web/ikaantyminen/palvelujen-ja-hoidon-laatu/raivertailukehittaminen/tietoa-rai-jarjestelmasta. (2016, accessed 12 October 2016). 91. InterRAI. http://www.interrai.org/ (2016, accessed 10 August 2016). 92. National Institute for Health and Welfare. Sotkanet.fi. Statistical information on welfare and health in Finland. https://www.sotkanet.fi/sotkanet/fi/index (2016, accessed 10 October 2016).

93. Westra BL, Clancy TR, Sensmeier J, et al. Knowledge: Big Data ScienceImplications for Nurse Leaders. Nurs Adm Q 2015; 39: 304-10.

94. Topaz M, Troutman-Jordan M and MacKenzie M. Construction, Deconstruction, and Reconstruction: The Roots of Successful Aging Theories. Nurs Sci Q 2014; 3: 226233. 
95. Harden JT and Watman RA. The National Hartford Center of Gerontological Nursing Excellence: An Evolution of a Nursing Initiative to Improve Care of Older Adults. Gerontologist 2015; 55: S1-12.

96. Dundar Y, Dodd S, Dickson R, et al. Comparison of conference abstracts and presentations with full-text articles in the health technology assessments of rapidly evolving technologies. Health Technol Assess 2006; 10: iii-iv, ix-145.

97. Grant MJ and Booth A. A typology of reviews: an analysis of 14 review types and associated methodologies. Health Info Libr J 2009; 26: 91-108.

98. Peltomäki P. The Well-Being in the Family of an Elderly Person Living at Home - A Phenomenological-Hermeneutical Research. PhD Thesis, Acta Universitatis Tamperensis 1957, University of Tampere (In Finnish, English abstract), 2014.* 99. Rantala M. Nurses' evaluations of postoperative pain management in patients with dementia. PhD Thesis, Publications of the University of Eastern Finland 230, University of Eastern Finland, 2014.*

100. Nikkola R. Polven nivelrikon sairastaminen iäkkään potilaan ja läheisen kokemana. PhD Thesis, Acta Universitatis Tamperensis 1811, University of Tampere (In Finnish), 2013.*

101. Frilund M. A synthesizer of Caring science and nursing intensity. PhD Thesis, Åbo Akademi University, Department of Caring Sciences (In Swedish, English abstract), 2013.* 
102. Turk E. Patient reported outcomes in elderly patients with diabetes mellitus type 2 in Slovenia. PhD Thesis, Acta Universitatis Ouluensis D1226, University of Oulu, 2013.*

103. Vuoti M. Visions of the future about ageing, well-being and social and health care services among baby boomers in Northern Finland. PhD Thesis, Acta Universitatis Ouluensis D1114, University of Oulu (In Finnish, English abstract), 2011.* 104. Vähäkangas P. Rehabilitation nursing care: practices and leadership. PhD Thesis, Acta Universtitatis Ouluensis D1060, University of Oulu (In Finnish, English abstract), 2010.*

105. Eloranta S. Supporting older people's independent living at home through social and health care collaboration. PhD Thesis, Annales Universitatis Turkuensis D869, University of Turku, 2009.*

106. Söderlund M. As if struck by a hurricane: The situation of the relatives of someone suffering from dementia. $\mathrm{PhD}$ Thesis, Åbo Akademi University, Department of Caring Sciences (In Swedish, English abstract), 2004.*

107. Pyykkö V. "If only I could" "There is always a loophole”. Hope and hopelessness experienced by the severely depressive and non-depressive elderly. $\mathrm{PhD}$ Thesis, Annales Universitatis Turkuensis D577, University of Turku, 2003.* 108. Mäkinen B. The relatives of elderly patients in specialized nursing care. The viewpoint of the relative, the physician and the nurse. $\mathrm{PhD}$ Thesis, Annales 
Universitatis Turkuensis 183, University of Turku (In Finnish, English abstract), 2002.*

109. Hantikainen V. Restraint use in older nursing home residents: nursing staff perceptions and decision-making in swiss nursing homes. PhD Thesis, Annales Universitatis Turkuensis D418, University of Turku, 2000.* 110. Rissanen L. Ability of elderly people to cope at home. Health, functional capacity and subjective need for social and health care services among people aged over 65. PhD Thesis, University of Oulu (In Finnish, English abstract), 1999.* 
Table 1. Dissertations published in universities

\section{Dissertation}

type

Portion of dissertations

focusing on older people from

all dissertations

Unive Compil Monog In total and proportion Grand in nursing science published in

rsity ation raph of dissertations*

\begin{tabular}{lrrrrr} 
rsity & ation & \multicolumn{1}{l}{ raph } & \multicolumn{1}{l}{ of dissertations } & \multicolumn{1}{l}{ total\# } & Finland \\
\hline UEF & 5 & 3 & $8(18,2 \%)$ & 110 & $7,30 \%$ \\
TaY & 1 & 5 & $6(13,7 \%)$ & 80 & $7,50 \%$ \\
UTU & 9 & 5 & $14(31,8 \%)$ & 103 & $13,60 \%$ \\
OY & 5 & 9 & $14(31,8 \%)$ & 69 & $20,30 \%$ \\
AA & 1 & 1 & $2(4,5 \%)$ & 56 & $3,60 \%$ \\
Total & 21 & 23 & 44 & 418 & $10,50 \%$ \\
\hline
\end{tabular}

* In total= dissertation with focus to older people

nursing

\# Grand total $=$ dissertations published in total till the

end of 2015 
Table 2. Type of the dissertation and paradigm in nursing science

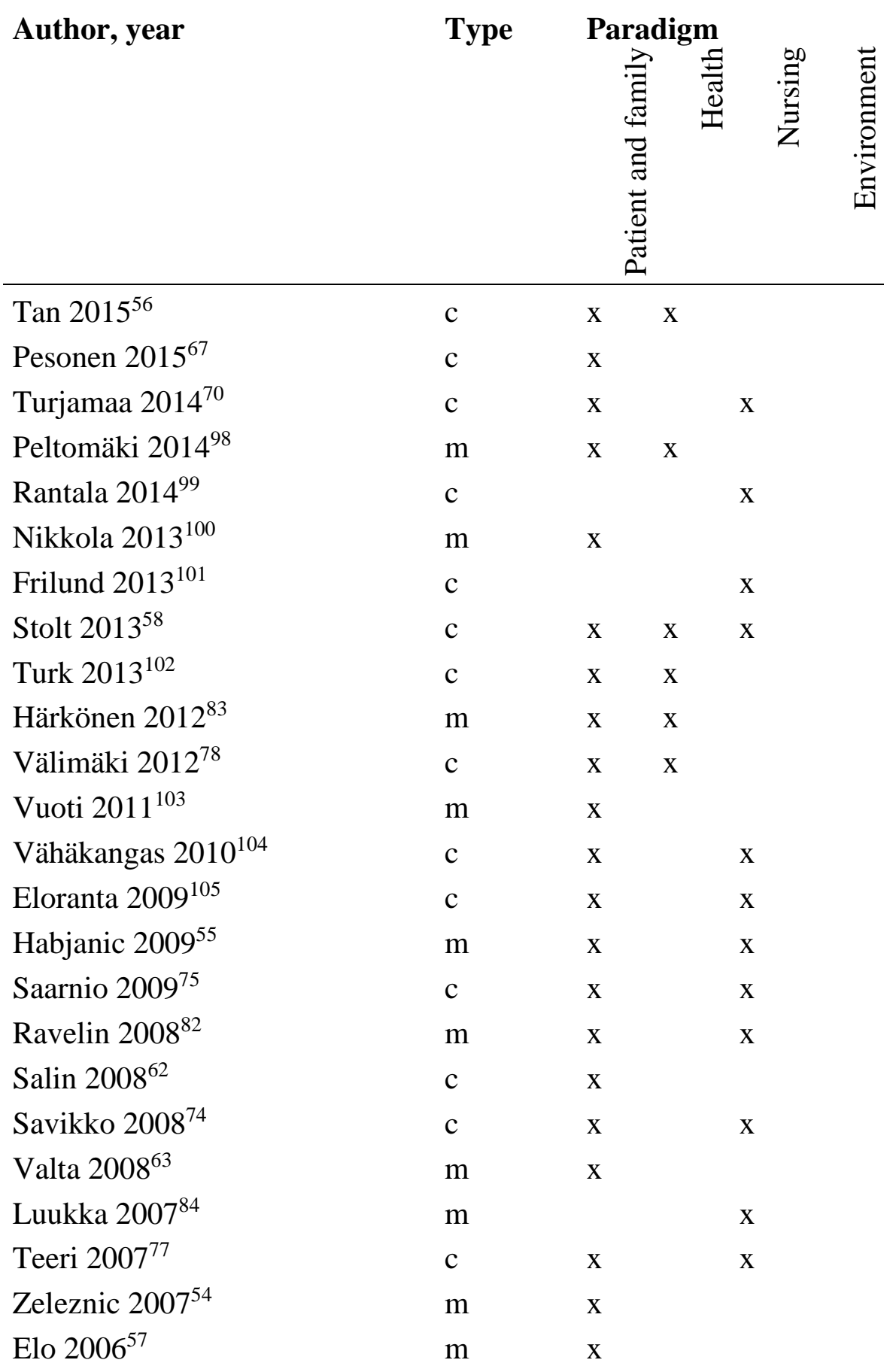


Klemola $2006^{73}$

Lepistö $2004^{59}$

Soini $2004^{81}$

Söderlund 2004 ${ }^{106}$

Koponen $2003^{66}$

Muurinen $2003^{76}$

Pyykkö 2003 107

Lukkaroinen $2002^{61}$

Mäkinen $2002^{108}$

Paasivaara $2002^{69}$

Pirilä $2002^{80}$

Backman 200164

Hantikainen $2000^{109}$

Arve $1999^{79}$

Rissanen $1999^{110}$

Routasalo $1997^{72}$

Sonninen $1997^{60}$

Laitinen $1996^{68}$

Nores $1992^{65}$

Liukkonen $1990^{71}$

\begin{tabular}{|c|c|c|c|}
\hline $\mathrm{m}$ & $X$ & & $\mathrm{X}$ \\
\hline$c$ & & & $X$ \\
\hline c & & & $\mathrm{X}$ \\
\hline $\mathrm{m}$ & $X$ & $X$ & \\
\hline $\mathrm{m}$ & $X$ & & \\
\hline $\mathrm{m}$ & $X$ & & $\mathrm{X}$ \\
\hline $\mathrm{m}$ & $\mathrm{X}$ & & \\
\hline $\mathrm{m}$ & & & $\mathrm{X}$ \\
\hline $\mathrm{m}$ & $X$ & & $\mathrm{X}$ \\
\hline $\mathrm{m}$ & & & $X$ \\
\hline $\mathrm{m}$ & $\mathrm{X}$ & $X$ & \\
\hline$c$ & $X$ & & \\
\hline$c$ & $X$ & & $\mathrm{X}$ \\
\hline$c$ & $X$ & $\mathrm{X}$ & \\
\hline $\mathrm{m}$ & $X$ & & \\
\hline$c$ & & & $\mathrm{X}$ \\
\hline $\mathrm{m}$ & $X$ & & \\
\hline $\mathrm{c}$ & X & & $\mathrm{X}$ \\
\hline $\mathrm{m}$ & $X$ & & \\
\hline $\mathrm{m}$ & X & & \\
\hline
\end{tabular}


Table 3. Topics of the dissertations

\begin{tabular}{|c|c|c|}
\hline Topic & & Reference \\
\hline \multicolumn{3}{|l|}{$\begin{array}{l}\text { Care procedures, clinical } \\
\text { nursing }\end{array}$} \\
\hline & $\begin{array}{l}\text { Post-operative pain } \\
\text { management }\end{array}$ & Rantala $2014^{99}$ \\
\hline & $\begin{array}{l}\text { Foot health, knowledge and } \\
\text { activities }\end{array}$ & Stolt $2013^{58}$ \\
\hline & $\begin{array}{l}\text { Synthesizer of caring science } \\
\text { between caring ethos and } \\
\text { nursing intensity }\end{array}$ & Frilund $2013^{101}$ \\
\hline & $\begin{array}{l}\text { Physical restraints, restrains } \\
\text { use }\end{array}$ & $\begin{array}{l}\text { Saarnio } 2009^{75}, \\
\text { Hantikainen } 2000^{109}\end{array}$ \\
\hline & Institutional respite care & Salin $2008^{62}$ \\
\hline & Dance performance & Ravelin $2008^{82}$ \\
\hline & Nutrition & Soini $2004^{81}$ \\
\hline & Pressure ulcer risk & Lepistö $2004^{59}$ \\
\hline & $\begin{array}{l}\text { Respite care, staff and } \\
\text { nursing }\end{array}$ & Muurinen $2003^{76}$ \\
\hline & Evolution of geriatric nursing & Paasivaara $2002^{69}$ \\
\hline & Oral care in institutions & Pirilä 2002 \\
\hline & $\begin{array}{l}\text { Recognition of depressive } \\
\text { elderly }\end{array}$ & Arve $1999^{79}$ \\
\hline & Touch & Routasalo $1997^{72}$ \\
\hline & $\begin{array}{l}\text { Participation in care and care } \\
\text { quality }\end{array}$ & Laitinen $1996^{68}$ \\
\hline & $\begin{array}{l}\text { Basic care of demented } \\
\text { patients }\end{array}$ & Liukkonen $1990^{71}$ \\
\hline \multicolumn{3}{|l|}{$\begin{array}{l}\text { Self-care, independence of } \\
\text { older people }\end{array}$} \\
\hline & Resources, reality orientation & Turjamaa $2014^{70}$ \\
\hline & $\begin{array}{l}\text { Sense of coherence, } \\
\text { adaptation }\end{array}$ & Välimäki $2012^{78}$ \\
\hline & Rehabilitation & Vähäkangas $2010^{104}$ \\
\hline & $\begin{array}{l}\text { Independent living, } \\
\text { collaboration }\end{array}$ & Eloranta $2009^{105}$ \\
\hline & Daily performance & Valta $2008^{63}$ \\
\hline & Self-care & $\begin{array}{l}\text { Zeleznic } 2007^{54} \\
\text { Backman } 2001^{64}\end{array}$ \\
\hline
\end{tabular}




\begin{tabular}{|c|c|c|}
\hline & $\begin{array}{l}\text { Shared responsibility, living } \\
\text { home }\end{array}$ & Lukkaroinen $2002^{61}$ \\
\hline & Ability to cope & Rissanen $1999^{110}$ \\
\hline & $\begin{array}{l}\text { Evaluation of appraisal of } \\
\text { self-care agency }\end{array}$ & Sonninen $1997^{60}$ \\
\hline \multicolumn{3}{|l|}{$\begin{array}{l}\text { Being, existence of being } \\
\text { old }\end{array}$} \\
\hline & $\begin{array}{l}\text { Living with memory disorder } \\
\text { diagnosis }\end{array}$ & Pesonen $2015^{67}$ \\
\hline & Suffering from osteoarthritis & Nikkola $2013^{100}$ \\
\hline & Loneliness & Savikko $2008^{74}$ \\
\hline & Integrity, ethical problems & Teeri $2007^{77}$ \\
\hline & Situation, relatives, dementia & Söderlund $2004^{106}$ \\
\hline & Hope, hopelessness & Pyykkö 2003 $3^{107}$ \\
\hline & $\begin{array}{l}\text { Being a relative, while older } \\
\text { person in hospital }\end{array}$ & Mäkinen $2002^{108}$ \\
\hline & Experience of existence & Nores $1992^{65}$ \\
\hline \multicolumn{3}{|l|}{$\begin{array}{l}\text { Quality of life, well-being } \\
\text { and life satisfaction of } \\
\text { older people }\end{array}$} \\
\hline & Quality of life and health & $\operatorname{Tan} 2015^{56}$ \\
\hline & Well-being of family & Peltomäki $2014^{98}$ \\
\hline & Life satisfaction and health & Härkönen $2012^{83}$ \\
\hline & Ageing, well-being, services & Vuoti $2011^{103}$ \\
\hline & Perception of quality of care & Habjanic $2009^{55}$ \\
\hline & $\begin{array}{l}\text { Environment supporting } \\
\text { well-being }\end{array}$ & Elo $2006^{57}$ \\
\hline \multirow[t]{2}{*}{ Transition } & Between home and hospital & Koponen $2003^{66}$ \\
\hline & Leaving one's home & Klemola $2006^{73}$ \\
\hline \multicolumn{3}{|l|}{ Knowledge, learning } \\
\hline & $\begin{array}{l}\text { Diabetes knowledge and } \\
\text { quality of life }\end{array}$ & Turk $2013^{102}$ \\
\hline & $\begin{array}{l}\text { Meaningful learning in } \\
\text { elderly care }\end{array}$ & Luukka $2007^{84}$ \\
\hline
\end{tabular}


Table 4. Informants, methods and settings of the dissertations

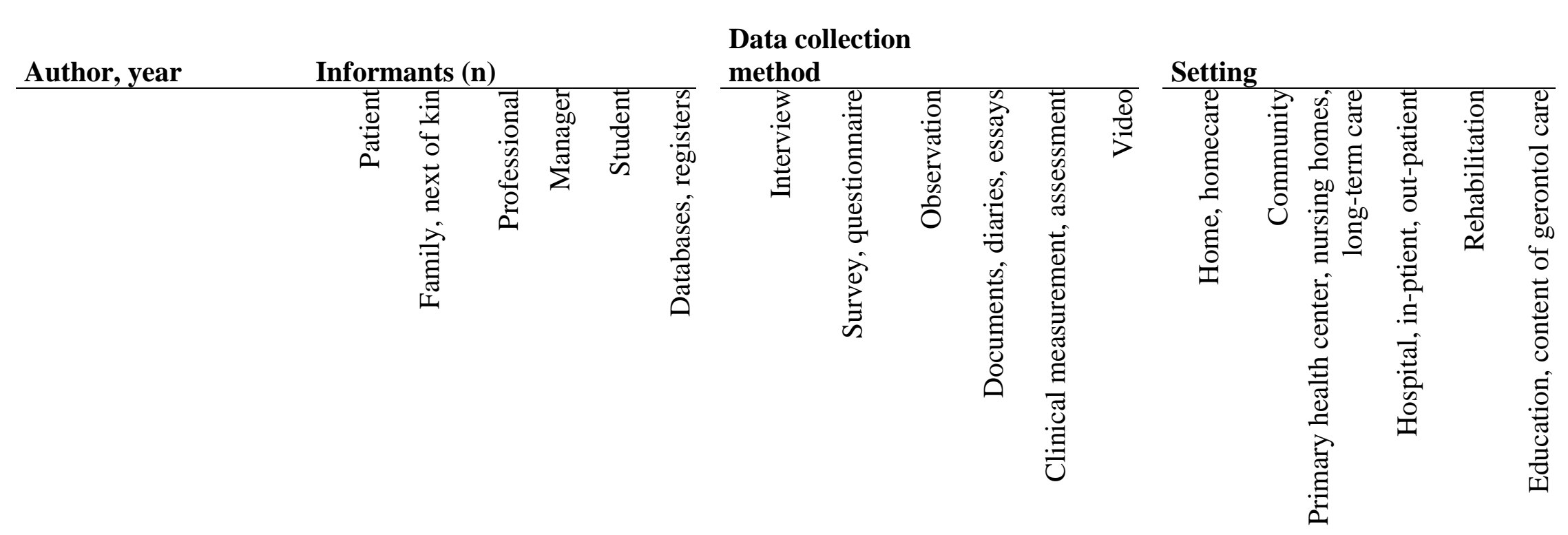

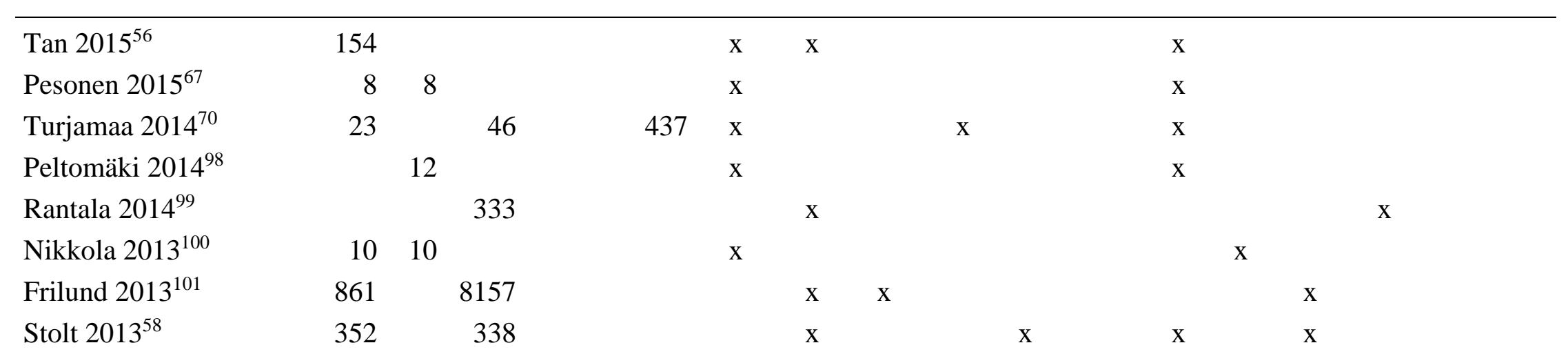




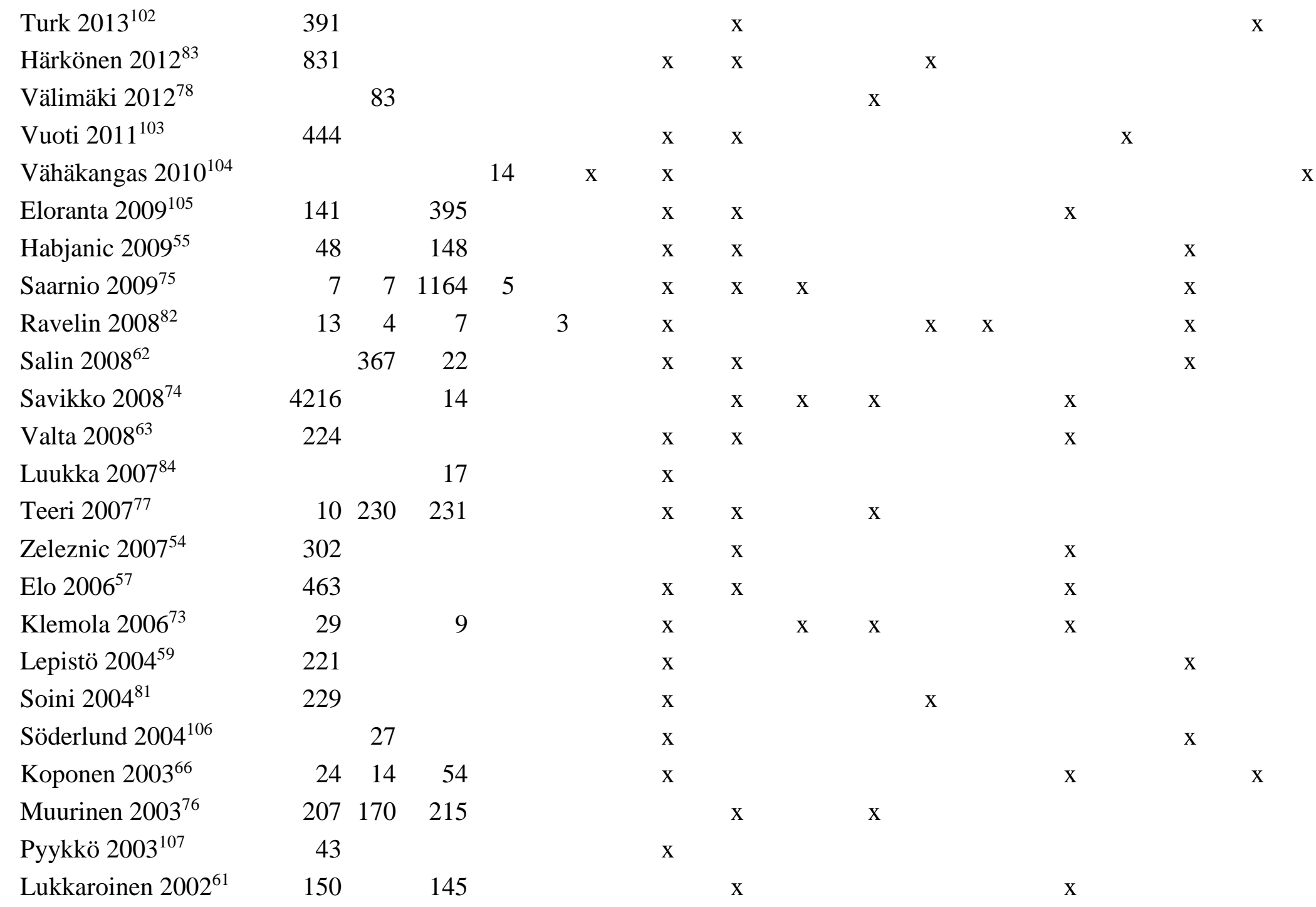




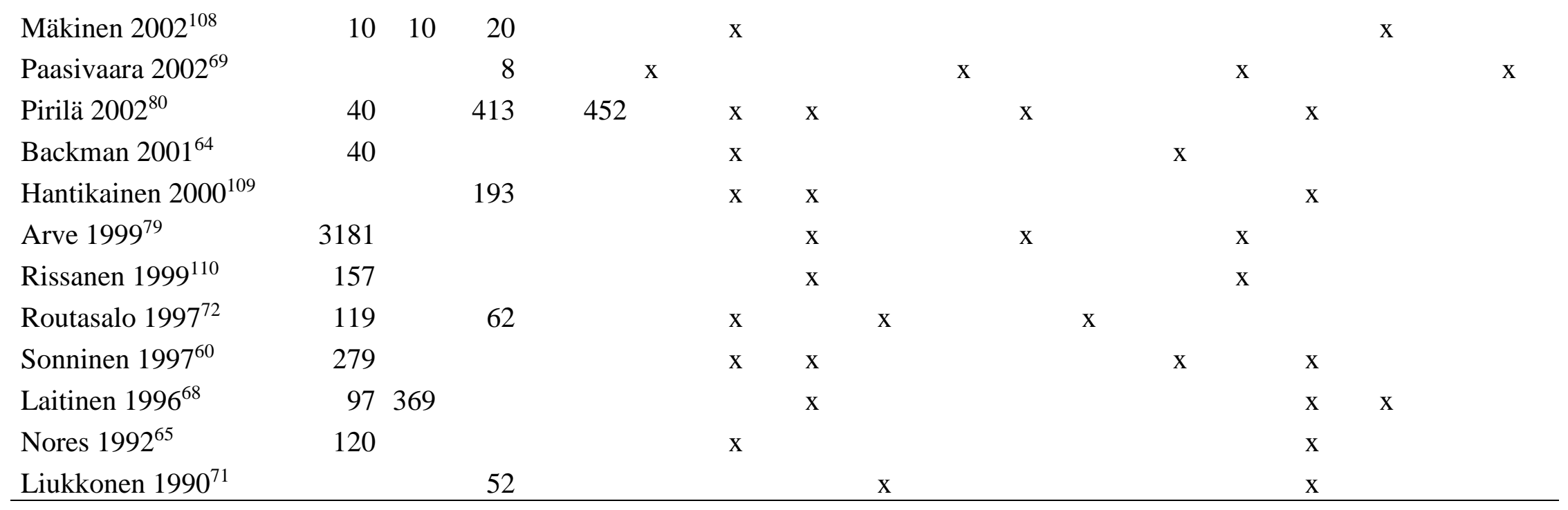

